\title{
Reduction of Organic and Inorganic Pollutant from Waste Water by Algae
}

\author{
Omprakash Sahu \\ Department of Chemical Engineering, KIOT Wollo University Kombolcha (SW), Ethiopia \\ Tel: +251933520653 \\ E-mail address: lops0121@gmail.com
}

\begin{abstract}
Recently, algae have become significant organisms for biological purification of wastewater since they are able to accumulate plant nutrients, heavy metals, pesticides, organic and inorganic toxic substances and radioactive matters in their cells/bodies. Biological wastewater treatment systems with micro algae have particularly gained importance in last 50 years and it is now widely accepted that algal wastewater treatment systems are as effective as conventional treatment systems. These specific features have made algal wastewaters treatment systems an significant low-cost alternatives to complex expensive treatment systems particularly for purification of municipal wastewaters. By this method $70 \%$ of biological oxygen demand, $66 \%$ of chemical oxygen demand, $71 \%$ total nitrogen, $67 \%$ of phosphorus, $54 \%$ volatile solid and $51 \%$ of dissolved solid was reduced.
\end{abstract}

Keywords: Biological; Chemical; Dissolved; Nutrition; Organic

\section{INTRODUCTION}

Phycoremediation is the process of employing algae for improving water quality. Algae can fix carbon dioxide by photosynthesis and remove excess nutrients effectively at minimal cost. In addition, photosynthetically produced oxygen can relieve biological oxygen demand (BOD) in the waste water [1]. Micro algae are superior in remediation processes as a wide range of toxic and other wastes can be treated with algae and they are non pathogenic. The risk of accidental release of pollutants into the atmosphere causing health safety and environmental problems are avoided when algae are employed for remediation. Algae utilize the wastes as nutritional sources and enzymatically degrade the pollutants [2]. The xenobiotics and heavy metals are known to be detoxified/ transformed/or volatilized by algal metabolism. They have the ability to take up various kinds of nutrients like nitrogen and phosphorus [3]. They can utilize various organic compounds containing nitrogen and phosphorus from their carbon sources. Many researchers have studied micro algae as possible solution for environmental problems [4]. Algal growth can keep the water clean and make natural waters more suitable for human consumption.

The choice of micro algae to be used in wastewater treatment is determined by their robustness against wastewater and by their efficiency to grow in and to take up nutrients from wastewater [5]. In well oxygenated high rate ponds, climax cultures that are not readily grazed consist mainly of coccoid green algae forms. Some algae which are generally used for 
the waste water treatment are Chlorella, Scenedesmus, Synechoccystis, Gloeocapsa, Chroococcus, Anabaena, Lyngbya, Oscillatoria, Spirulina etc.

There are a symbiotic relation among bacteria and algae in aquatic ecosystems. Algae support to aerobic bacterial oxidation of organic matter producing oxygen via photosynthesis whilst released carbon dioxide and nutrients in aerobic oxidation use for growth of algal biomass. Considering ammonium, carbon dioxide and orthophosphate as main nutrient sources, Oswald determined that oxygen release ratio is $1.5 \mathrm{~g} \mathrm{O}_{2} / 1 \mathrm{~g}$ algal biomass [6]. Grobbelaar et al. reported to oxygen release ratio of $1.9 \mathrm{~g} \mathrm{O}_{2} / 1 \mathrm{~g}$ algal biomass [7]. Arceivala, accounting latitude, climate and atmospheric conditions, calculated that 4-6\% of mean daily solar radiation reaching on treatment pond in $40^{\circ} \mathrm{N}$ latitude use for new biomass production and production rate of algal biomass may reach $80 \mathrm{~kg} \mathrm{O}_{2} / 1$ ha-day [8].

Most of nitrogen in algal cell bound to proteins which compose to $45-60 \%$ of dry weight and phosphorus is essential for synthesis of nucleic acids, phospholipids and phosphate esters. Algae using nitrogen and phosphorus in growth may remove to nutrients load of wastewater from a few hours to a few days [9]. In comparison to common treatment systems, oxidation ponds supporting growth of some species may be effective of nutrient removal. Increasing dissolved oxygen concentration and $\mathrm{pH}$ cause for phosphorus sedimentation, ammonia and hydrogen sulphur removal. High $\mathrm{pH}$ in algal ponds also leads to pathogen disinfection [10].

Removal efficiency of heavy metals by algae shows changes among species. In fact, studies showed that chrome by Oscillatoria, cadmium, copper and zinc by Chlorella vulgaris, lead by Chlamydomonas and molybdenum by Scenedesmus chlorelloides may remove successfully [11-15]. Although algae have adaptation ability to sub-lethal concentrations, accumulation of heavy metals in cells may be potentially toxic effects to the other circles of food web [16].

Treatment of wastewater depends upon the nature of the wastewater as well as the economical status. For the low cost types of treatment photoremediation proof best as compared to other. So through this study attempted has been made to reduce the physicochemical parameter of municipal waste water. The studies focus on the reduction on BOD, COD, nutrition and dissolved solid present in the waste water.

\section{MATERIAL AND METHODS}

\section{1. Microalgae Strain}

There are many species and genus of algae suitable for nutrients removal. In this project, the microalgae strain- Chlorella vulgaris (Chlorophyceae) was used. This strain was obtained from local area. The culture was collected as inoculums in four flasks of $200 \mathrm{~mL}$ each.

\section{2. Sample Collection}

The wastewater sample was collected from a sewage treatment plant located at Kombolcha town. The characteristics of the wastewater was analyzed in order to determine the chemical oxygen demand (COD), biological oxygen demand (BOD), total nitrogen (TN), total phosphorus (TP), total dissolved solids (TDS) and volatile suspended solids (VSS). 


\section{3. Algal Growth in Suspension}

The medium was prepared from the stock solution. The $\mathrm{pH}$ was adjusted to 6.8-7.0 using 1 molar $\mathrm{KOH}$ with magnetic stirrer and hot plate.

The media was autoclaved at $121^{\circ} \mathrm{C}$ for 15 minutes and it was allowed to cool for 2 hours to attain room temperature. Then the media was transferred to five $250 \mathrm{~mL}$ shake flasks as $90 \mathrm{~mL}$ per flask. About $10 \mathrm{~mL}$ inoculums were transferred to all flasks and each flask was closed by cotton and then covered by aluminum foil.

This step was done within laminar flow hood. All the $250 \mathrm{~mL}$ flasks were inserted to shaker at $110 \mathrm{rpm}$ for 1 week at room temperature in 12 hours light and 12 hours dark cycles.

\section{4. Transfer to Wastewater}

The dry concentration $(\mathrm{mg} / \mathrm{L})$ of the Chlorella vulgaris obtained was determined by filtration of a culture liquors sample through GC paper and oven drying at $103-105{ }^{\circ} \mathrm{C}$ for about 1 hour. Based on the dry weight result, Chlorella vulgaris inocula for succeeding test were adjusted to $100 \mathrm{mg} / \mathrm{L}$ by addition of an appropriate amount of wastewater.

The 14 shake flasks $(250 \mathrm{~mL})$ were used containing partially treated wastewater $(50$ $\mathrm{mL}$ ) inoculated with Chlorella vulgaris of $100 \mathrm{mg} / \mathrm{L}$ concentration. Another 14 shake flasks $(250 \mathrm{~mL})$ containing wastewater without algae was used as control.

The study was conducted under batch culture process in the laboratory under fluorescent tube light for 12 hours per day. All samples were incubated at $110 \mathrm{rpm}$ continuously up to 21 days. Sample was collected and analyzed after two days (odd sequence) for 21 days and for total nitrogen (TN), total phosphorus (TP), chemical oxygen demand (COD), biological oxygen demand (BOD), dissolved solid (DS) and volatile suspended solids (VSS).

\section{5. Laboratory Tests}

Total nitrogen (TN), total phosphorus (TP), chemical oxygen demand (COD), biological oxygen demand (BOD), dissolved solid (DS) and volatile suspended solids (VSS) were analyzed according to the standard methods [17].

\section{RESULT AND DISCUSSION}

\section{1. Reduction of COD and BOD}

The effect of algae (photoremediation) on COD and BOD reduction was carried out 21 day continuously. The reduction was expressed in graphically manner which shown in Fig. 1. It was found that COD 18, 23, 27, 30, 34.5, 39, 44.5, 51, 56, 60.9 \% and BOD 20, 24.6, 29, $33,38,42,47,54,59,64 \%$ reduction was increase with increasing in $1,3,5,7,9,11,13,15$, 17, 19days.

The maximum COD $66 \%$ and BOD $70 \%$ reduction was observed on 21 days. The result agreed with other studies such as Aziz and $\mathrm{Ng}$ [18], who found that maximum percent removal for $\mathrm{COD} 72 \%$ and $\mathrm{BOD} 74 \%$ using an activated algal process to treat wastewater. 


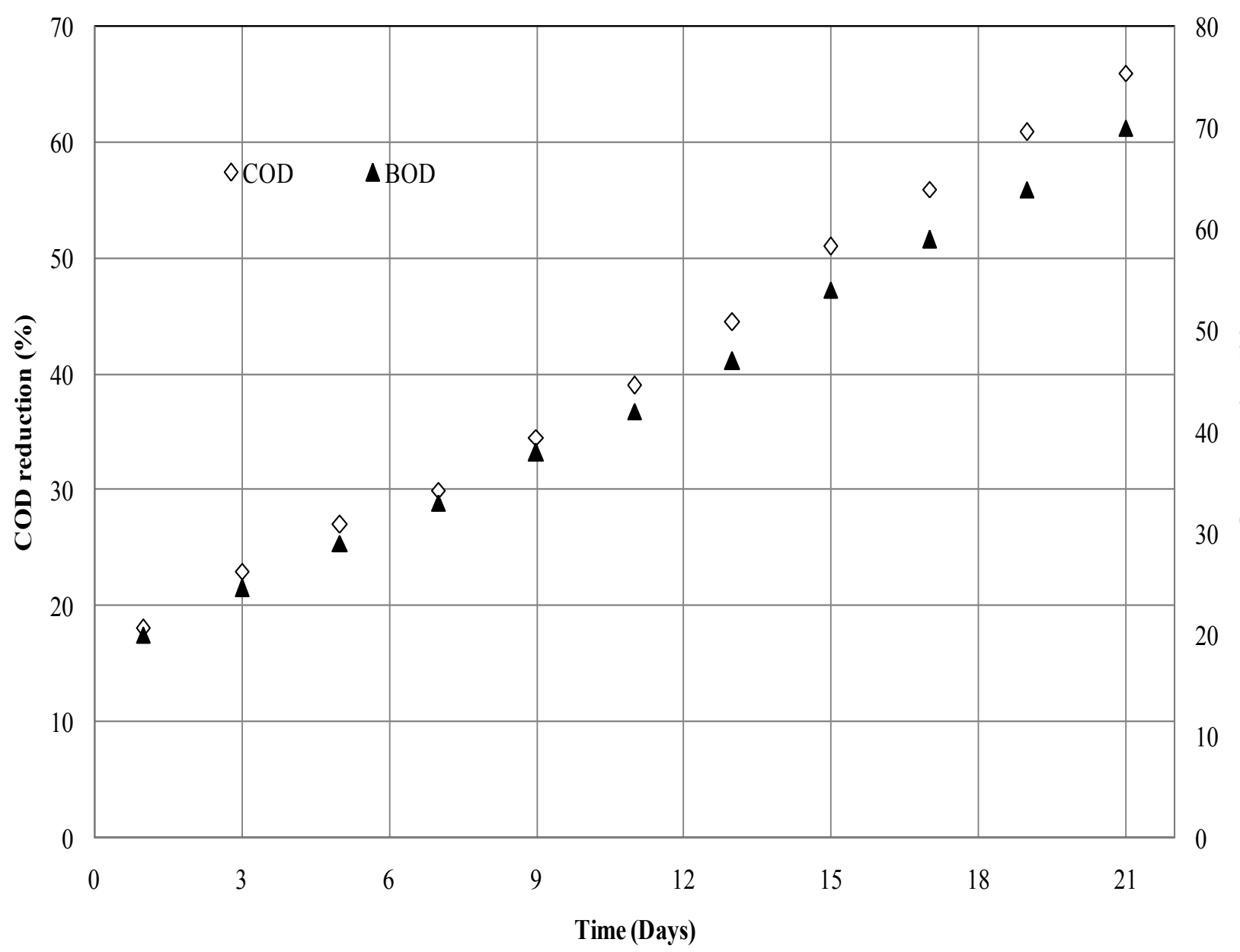

Fig. 1. Effect of photoremediation on COD and BOD reduction for 21 days.

\section{2. Reduction of nutrients}

The effect of algae on reduction of nutrients was carried out for 21 days which is shown Fig. 2.

The maximum total phosphorus $67 \%$ and total nitrogen $71 \%$ was observed on 15 days. Initially the total phosphorus reduction $24,29,34,41,50,56,62 \%$ and total nitrogen reduction $26,32,38,44,53,59,65 \%$ was found upto 13 days and then it was decreases 60 , $54,49 \%$ total phosphorus and $67,62,56 \%$ total nitrogen from 17 to 21 days. This result is quite similar to the study done by Sreesai and Pakpain [19].

They found that the maximum removal occurred on day 8 which was $88 \%$. The difference of removal occurred because they did the study under real sunlight while this study used the fluorescent light which gave different intensity. This result is far better than other studies such as by Gonzalez [20], who found that the microalgae Chlorella vulgaris removed $50 \%$ of TP from wastewater.

Likewise Weerawattanaphong [21], who cultured Chlorella vulgaris in poultry wastewater with a retention time of 8 days, found that maximum TP removal was $67 \%$. 


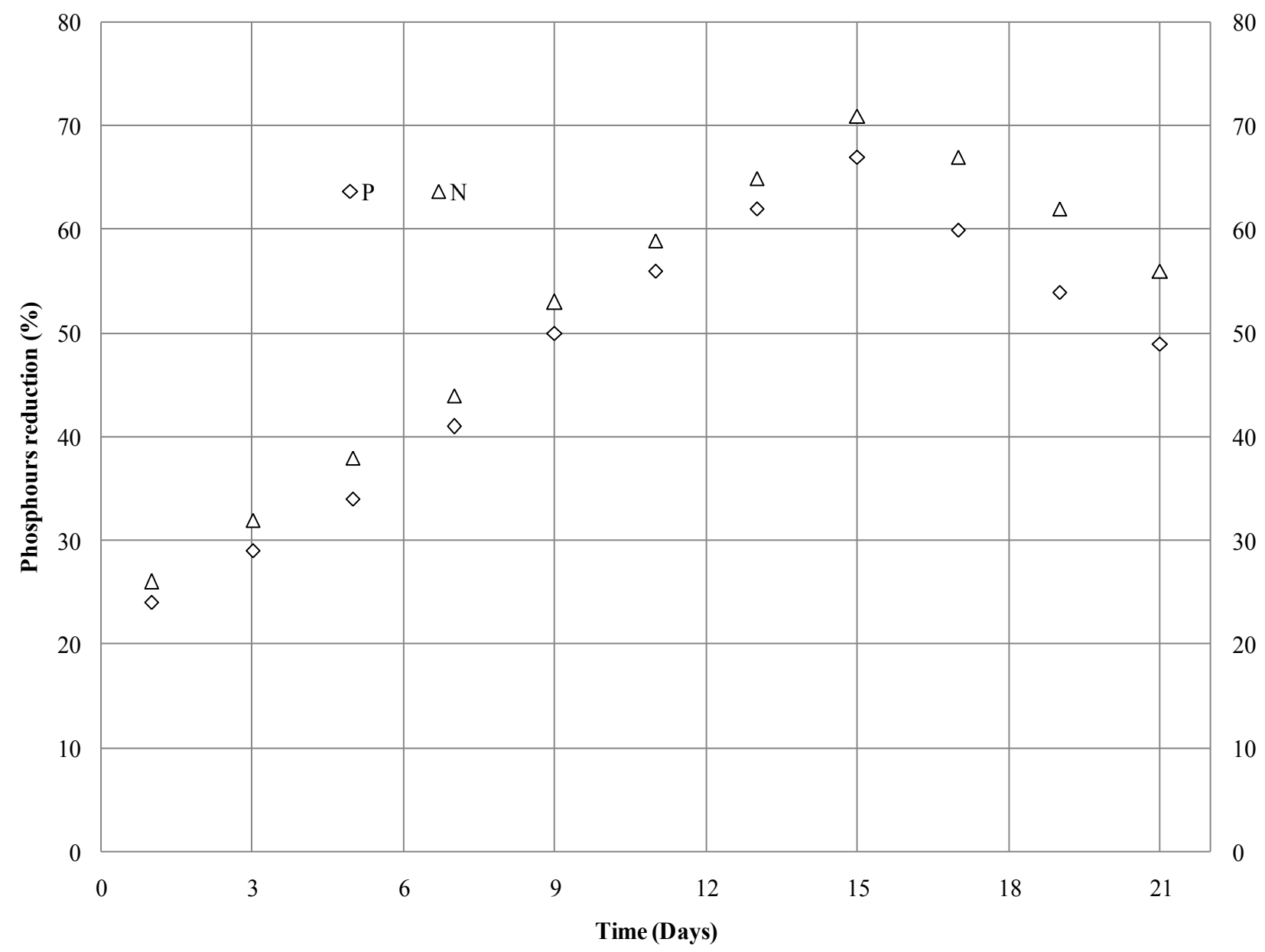

Fig. 2. Effect of photoremediation on total phosphorus (TP) and total nitrogen (TN) reduction for 21 days.

\section{3. Reduction of solid}

The reduction of dissolve solid and volatile solid was carried out for 21 days, which is shown in Fig. 3. It was found that the dissolved solid 18, 24, 29, 33, 38, 43, $49 \%$ and volatile solid $21,27,31,36,40,46,50 \%$ was increase with increase with treatments $1,3,5,7,9,11$, 13 days respectively. After that decrease 49, 47, $43 \%$ dissolved solid and 51, 49, $47 \%$ volatile solid from 17 to 21 days. The maximum reduction was found on 15 days of treatment that is $51 \%$ of dissolved solid and $54 \%$ of volatile solid. This occurred mainly because of the nutrients and other growth limiting factors [22,23].

The other limiting factors that might be considered include the concentrations or form of carbon source available in the culture medium and other organic growth promoters. In this experiment, there were no additions of any carbon sources, or trace elements to the treated wastewater to enhance or optimize Chlorella vulgaris growth. The results obtained was similar stated in the previous study by Bich et al. [24], who reported that the VSS concentration was within $26 \%$ of at 4 to 5 days. It is possible that algal biomass might have increased if mineral nutrients and some trace elements had been added. 


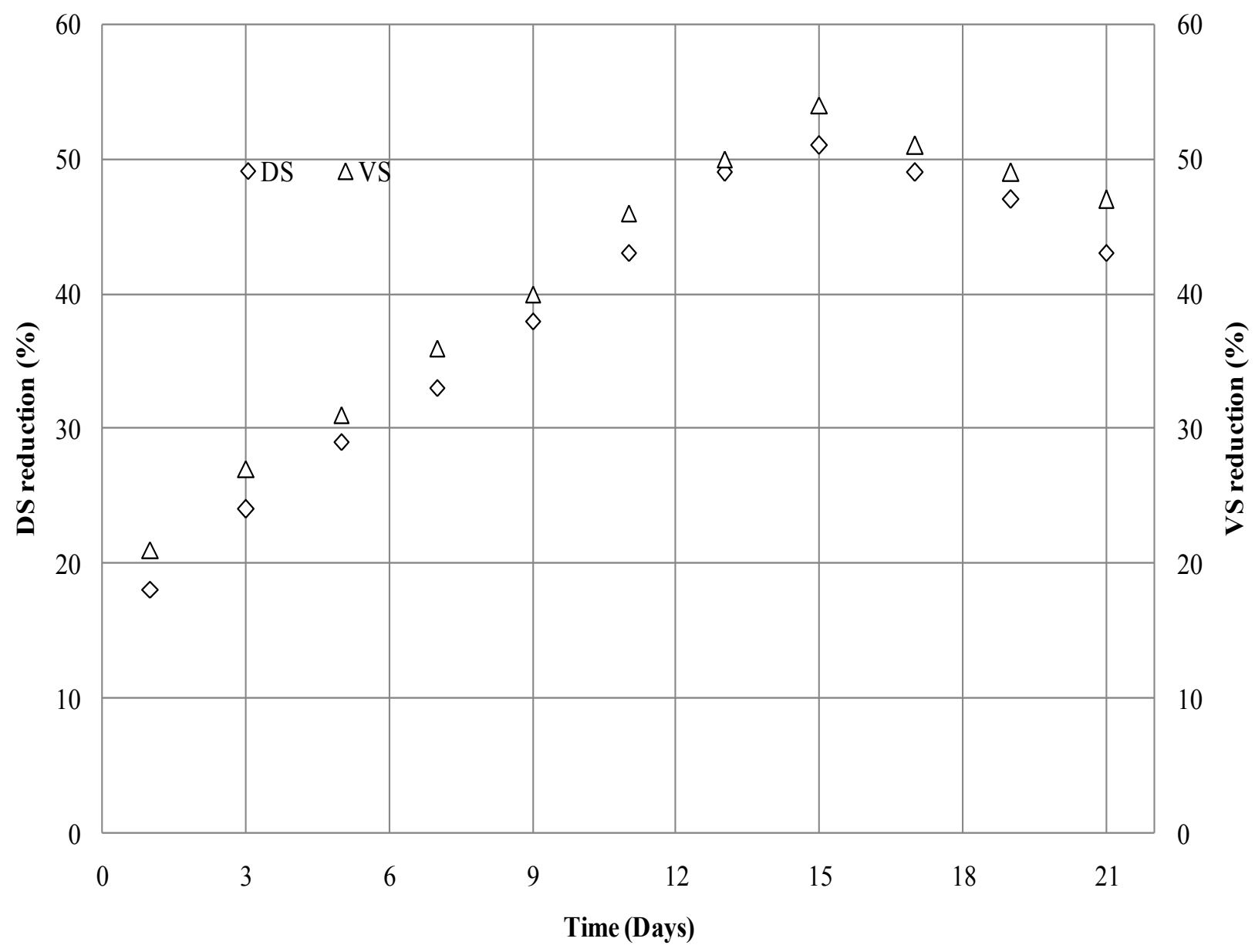

Fig. 3. Effect of photoremediation on dissolved solid (DS) and volatile solid (VS) reduction for 21 days.

\section{CONCLUSION}

Treatment with algae proof high efficient to reduce the pollution parameter, nutrient and dissolved solid found in wastewater. From the treatment $70 \%$ of biological oxygen demand, $66 \%$ of chemical oxygen demand, $71 \%$ total nitrogen, $67 \%$ of phosphorus, $54 \%$ volatile solid and $51 \%$ of dissolved solid was reduced. Both TN and TP removal in partially treated wastewater was governed by the growth of Chlorella vulgaris in combination with other microorganisms.

Therefore, Chlorella vulgaris is suitable for reduction of nutrient content in the wastewater in higher considerable amount and can help to achieve the effluent quality directive by the government environment protection agency and it is a good option of biological tertiary treatment of domestic wastewater treatment plant as well. 


\section{Reference}

[1] Laliberte, G., Proulx, D., De Pauw, N., La Noue J., Adv. Limnol. 42 (1994) 283-302.

[2] Oswald, W.J., Micro-algae and wastewater treatment. In: Borowitzka, M.A., Borowitzka, L.J. (Eds.), Micro-algal Biotechnology. Cambridge University Press, Cambridge, UK, 1998, 305-328.

[3] Pavasant, P., Apiratikul, R., Sungkhum, V., Suthiparinyanont, P., Wattanachira, S., Marhaba, T.F., Bioresour. Technol. 97 (2006) 2321-2329.

[4] Yoshida, N., Ishii, K., Okuno. T., Tanaka, K., Current Microbiology 52(6) (2006) 460463.

[5] Sen, A.K., Bhattacharya, M., Air and Soil Pollution 78 (1994) 141-152.

[6] Oswald, W.J. Microalgae and Wastewater Treatment. In: Microalgal Biotechnology, M.A. Borowitzka and L.J. Borowitzka (eds). Cambridge University Press, New York 1988b; pp. 357-94.

[7] Grobbelaar, J.U., Soeder, D.J., Stengel E., Biomass 21 (1990) 297-314.

[8] Arceivala, S.J., Metu Eng. Fac. Pub. 1973, No 44, Ankara.

[9] Lovaie, A. and De La Noüe, J., Water Res 19 (1985) 1437-1442.

[10] Laliberte, G., Proulx, D., De Pauw, N. and De La Noüe, J.,. Algal Technology in Wastewater Treatment. In: H. Kausch and W. Lampert (eds.), Advances in Limnology. E. Schweizerbart'sche Verlagsbuchhandlung, Stuttgart 1994; 283-382.

[11] Filip, D.S., Peters, T., Adams, V.D. and Middlebrooks, E.J., Water Res. 13 (1979) 305313.

[12] Nakajima, A., Horikoshi, T., and Sakaguchi, T., Eur. J. App. Microbiol. Biotechnol. 12 (1981) 76-83.

[13] Ting, Y.P., Lawson, E., Prince, I.G. Biotechnol. Bioeng. 34 (1989) 990-99.

[14] Hassett, J.M., Jennett, J.C., Smith, J.E., Appli. Environ. Microbiol. 41 (1981) 1097106.

[15] Sakaguchi, T., Nakajima A. and Horikoshi, T., Eur. J. App. Microbiol. Biotechnol. 12 (1981) 84-89.

[16] Wikfors, G.H., Ukeles, R., Mar. Ecol. Prog. Ser. 7 (1982) 191-206.

[17] APHA. "Standard methods for the examination of water and wastewater, 17th edition", American Public Health Association, Washington, DC, 1989.

[18] Aziz, M.A., Ng, W.J., Bioresource Technology 40 (2003) 205-208.

[19] Sreesai, S., Pakpain, P., Science Asia 33 (2007) 293-299.

[20] Gonzalez, L.E., Canizares, R.O., Baena, S., Bioresource Technology 60 (1997) 259262.

[21] Weerawattanaphong, W., Nutrients reduction from Science Asia poultry wastewater by green algae: Chlorella vulgaris" (M.Sc. thesis in Environmental Technology). Bangkok Faculty of Graduated studies, Mahidol University, Thailand, 1998. 
[22] Olguin, E.J., Biotechnology Adv. 22 (1992) 81-91.

[23] Sreesai, S., Asawasinsopon R., Satitvipawee P., Thammasat Intitude Journal of Science Technology 7(1) (2002) 13-19.

[24] Bich, N.N., Yaziz, M.I., Kadir, N.A., Water Resource 33 (1999) 2357-2362. 